\title{
原著
}

めまいを主訴とした小脳海綿状血管腫に静脈性血管腫を合併した一例 角谷 昌昭 ${ }^{1)}$ - 平山 肇 ${ }^{2)}$-中山 明峰3) - 稲福 繁3)

\section{A case of Cavernous Anginoma Associated with Venous Anginoma}

\author{
Masaaki Sumiya ${ }^{1)}$, Hajime Hirayama ${ }^{2)}$, Meiho Nakayama $^{3)}$, Shigeru Inafuku ${ }^{3)}$ \\ 1) Department of Otorhinolaryngology, Ensyu General Hospital \\ 2) Department of Otorhinolaryngology, Toki General Hospital \\ ${ }^{3)}$ Department of Otorhinolaryngology, Aichi Medical University
}

A 40-year-old male patient had a vertigo attack with vomiting; however, there was no hearing loss, headache, or palsy of arms or legs. On admission, the CT examination did not show any tumors, or infarctions of the brain, brain stem or cerebrum. Neurotological findings of an electro-nystagmography and caloric test did not show any abnormalities, except a platform test showed positive. Two days after admission, MRI examination showed a small mass $(15 \mathrm{~mm})$ in the left cerebellar peduncle. Previously, cavernous anginoma was considered rare, but the increasing use of MRI has demonstrated numerous cases. Typically, epileptic or other convulsive symptoms appear initially, but in our case, pathology was indicated by vertigo without other cranial nerve symptoms.

Key words: cavernous anginoma, vernous anginoma, vertigo

はじめに

頭蓋内海綿状血管腫（Cavernous Anginoma，以 下 CA）は比較的稀で，若年者に起こる脳内出血 の原疾患のひとつであるが，MRI の発達により 容易に診断がつくようになり報告は近年増加して きている。しかし，静脈性血管腫 (Venous Anginoma，以下 VA）を合併した CA 症例の耳鼻咽喉 科領域での報告はわれわれが渉弾し得たかぎり一 症例の報告しか見当たらない。今回突然のめまい を主訴とした一例を経験したので若干の文献的考 察を加えて報告する。

\footnotetext{
1) 静岡県厚生連遠州総合病院耳鼻咽喉科

2) 岐阜県土岐市立総合病院耳鼻咽㑨科

3) 愛知医科大学医学部耳鼻咽喉科
}

\section{症例}

症例：43歳男性。

主訴：めまい，嘔気，嘔吐。

既往歴：15歳, 腎結石, 40歳, 胃潰瘍。

現病歴：平成14年10月29日の昼に突然めまい, 嘔気, 湢吐が出現し，夕方になっても症状改善せ ず救命外来受診した。耳鼻咽喉科へ紹介され頭部 CTを施行したが明らかな異常を認めなかった。 初診時は耳症状, 頭痛, 意識障害はなく, めま い, 嘔気, 嘔吐, 歩行障害を認めた。微小循環改 善剤の点滴, 重炭酸水素ナトリウムの静注を施行 したが眼振が消失しないため入院となった。

\section{初診時所見}

頭位眼振検查：左水平性斜向性眼振を正中，左 右頭位で認めた（図 1)。 
指鼻試験：正常。

頭部 CT : 初診時に施行。大脳, 小脳, 脳幹, 小脳橋角部に明らかな異常は認めなかった（図 2 )。

\section{検查所見}

頭位眼振検査の経過：発症 2 日（10月30日）の 朝も左水平性斜行性眼振を認めたが, 夕方には眼 振は弱くなり発症 3 日目（10月30日）は一旦消失 した。発症 4 日目（11月3日）に正中，左右頭位 で左水平性眼振を認めたが発症 6 日目（11月 5 日）に完全に消失した。

標準純音聴力検査 (11月 6 日) : 両耳 $11.3 \mathrm{~dB}$ (4 分法)。

重心動摇検査（11月 6 日）：ロンベルグ率2.05
(14. 44/6. 06)。

カロリックテスト：発症後 7 日目（11月 6 日） に施行したが正常であった。

耳 X-P（シューラー，ステンバース法）：異常 なし。

血液生化学検査（10月30日）WBC: 16000, N/L: 88. 0/5. 9, CRP: 0. 04。

電気眼振図検査（ENG）: 発症後 8 日目（11月 6 日）に施行した。自発眼振，誘発眼振は認めな かった。ETT, OKP, OKN は正常所見であった (図 3 )。

頭部 MRI：入院 2 日目に施行。左小脳半球の 中央の白質に直径約 $10 \mathrm{~mm}$ の低信号，内部に一 部高信号域がみられる。T1 強調で低信号, T2 強
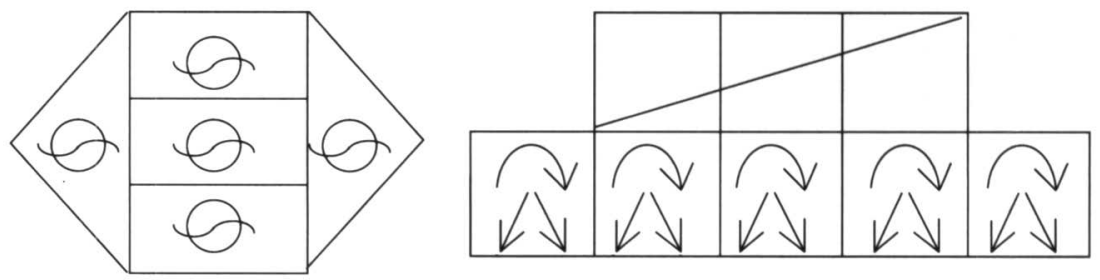

図 1 初診時の注視眼振検査, 頭位眼振検査

注視時は明らかな眼振は認めず，頭位変換眼振検査では左回旋性，斜行性眼振を認め中枢性疾患を疑っ た。

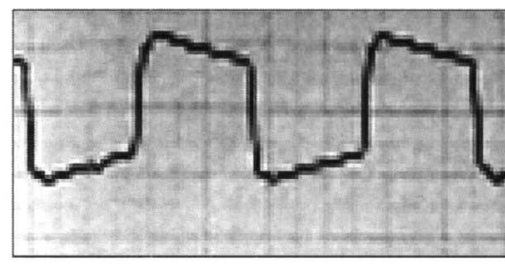

$20^{\circ}$

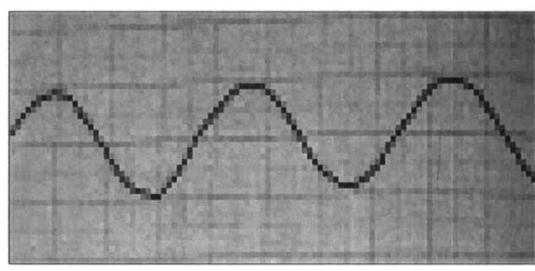

$20^{\circ}$

$10 \mathrm{~mm} / \mathrm{sec}$

$10 \mathrm{~mm} / \mathrm{sec}$

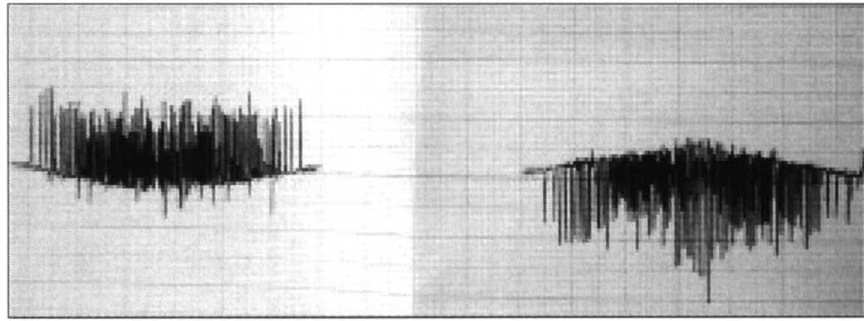

$1 \mathrm{~mm} / \mathrm{sec}$

図2 電気眼振図検査 (ENG)

ETT, OKP の波形を示す。急速眼球運動，追従眼球運動は正常。OKP も左右差なく眼振の解発は良好。 


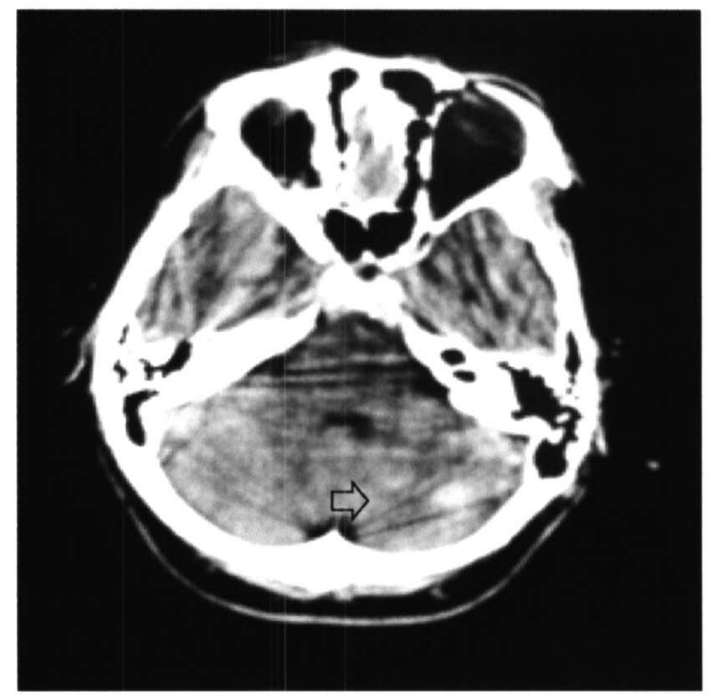

図 3 初診時頭部 CT

明らかな異常とは判断できなかったが，左 小脳半球に高吸収域が疑われる (矢印 $\Rightarrow) 。$

調で高信号，FLAIR で高信号を呈する線状のや や拡張した血管様構造がみられた（図 4,5)。

脳血管造影 (DSA)：一旦退院して脳神経外科 入院の上で左椎骨動脈造影を施行したところ, 静 脈相で後頭静脈洞から分岐する血管に umbrella sign を認めた（図6）。

以上のことから左小脳半球内部に静脈性血管腫 （VA）を合併した出血を伴ら海綿状血管腫（CA） であり,この CA 内部の出血によりめまい発作を 起こしたものと診断した。

\section{治療}

入院 2 日目の頭部 MRI で小脳海綿状血管腫が 疑われた時からグリセロール $400 \mathrm{ml} /$ 日の点滴静 注, 鎮暈剤, 抗不安薬を内服投与した。めまい症 状は入院翌日には軽快し, 入院後 6 日目には完全 に消失した。

\section{考察}

CA は耳鼻咽喉科領域の症状のみでの発症は極 めて稀で, てんかん, 頭痛, 脳出血で発症する ケースが多いといわれている1) 7)。出血源は血管 奇形が多く, 年齢的には20 50歳代に多く30歳代 以降にピークがあり, 男女差はない。発生頻度は $0.4 \sim 0.7 \%$ で，出血の頻度は0. 5〜 1\%とされてい る。 $80 \%$ はテント上にみられるが, 後頭蓋窩では 橋や小脳半球に好発する ${ }^{8)}$ 。

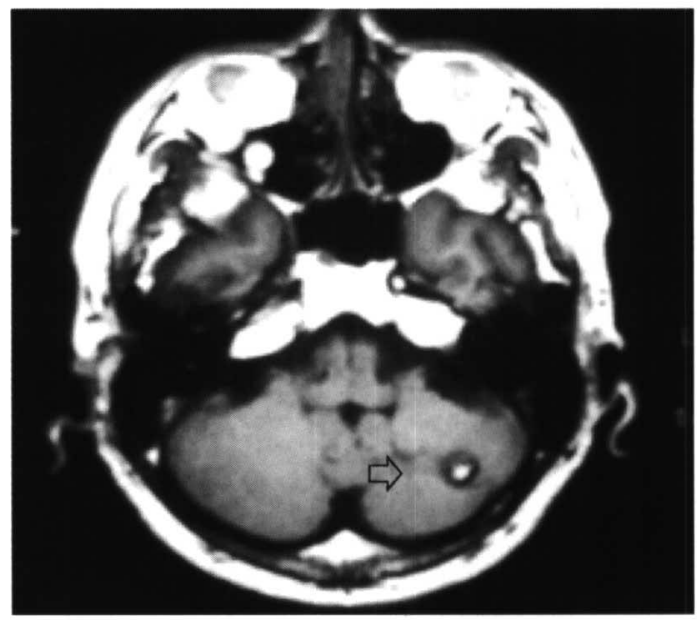

図4 入院 2 日目に施行した頭部 MRI（T2 強調） 左小脳半球の中央の白質に直径約 $10 \mathrm{~mm}$ の低信号, 内部に一部高信号域がみられる (矢印 $\Rightarrow)$ 。

VA は静脈が発達する過程での変異と考えられ ており，拡張した静脈よりなり放射状に配列する 骨道質静脈と 1 本の太い流出静脈をもつ。この特徵 は血管造影にて umbrella sign としてみられる。 好発部位は前頭葉, 小脳深部白質で最も多い血管 奇形である。一般に出血の頻度は極めて低いが, 後頭盍窩に発生するものでは合併した CA からの 出血で発症することがあるといわれている7 。

$\mathrm{CA}$ の CT 上の特徵は石灰化を含む辺縁明瞭な 不規則な形の高信号を呈し, mass effectは少な く造影効果があることが多い。MRI 上の特徵は $\mathrm{T} 2$ 強調像において内部は低信号から高信号が混 在するポップコーン様構造を示し, 周囲にへモジ デリンによる低信号帯を認める8)。今回の症例は 初診時には中枢性を疑ら眼振所見のみで初診時頭 部 CT では明らかな異常を認めなかったが，入院 2 日目の頭部 MRI では左小脳半球の中央の白質 に直径約 $10 \mathrm{~mm}$ の低信号, 内部に一部高信号域 がみられ，T1 強調で低信号， T2 強調で高信号， FLAIR で高信号を呈する線状のやや拡張した血 管様構造がみられた。このことから VA に合併し た CA と診断され，めまい発作が海綿状血管腫内 の出血により生じたと推察でき，頭部 MRIの有 用性を再認識した。しかしながら，電気眼振図検 査（ENG）では ETT，OKP，OKN で異常所見を 認めなかったので神経学的な特徴がそしい印象で 


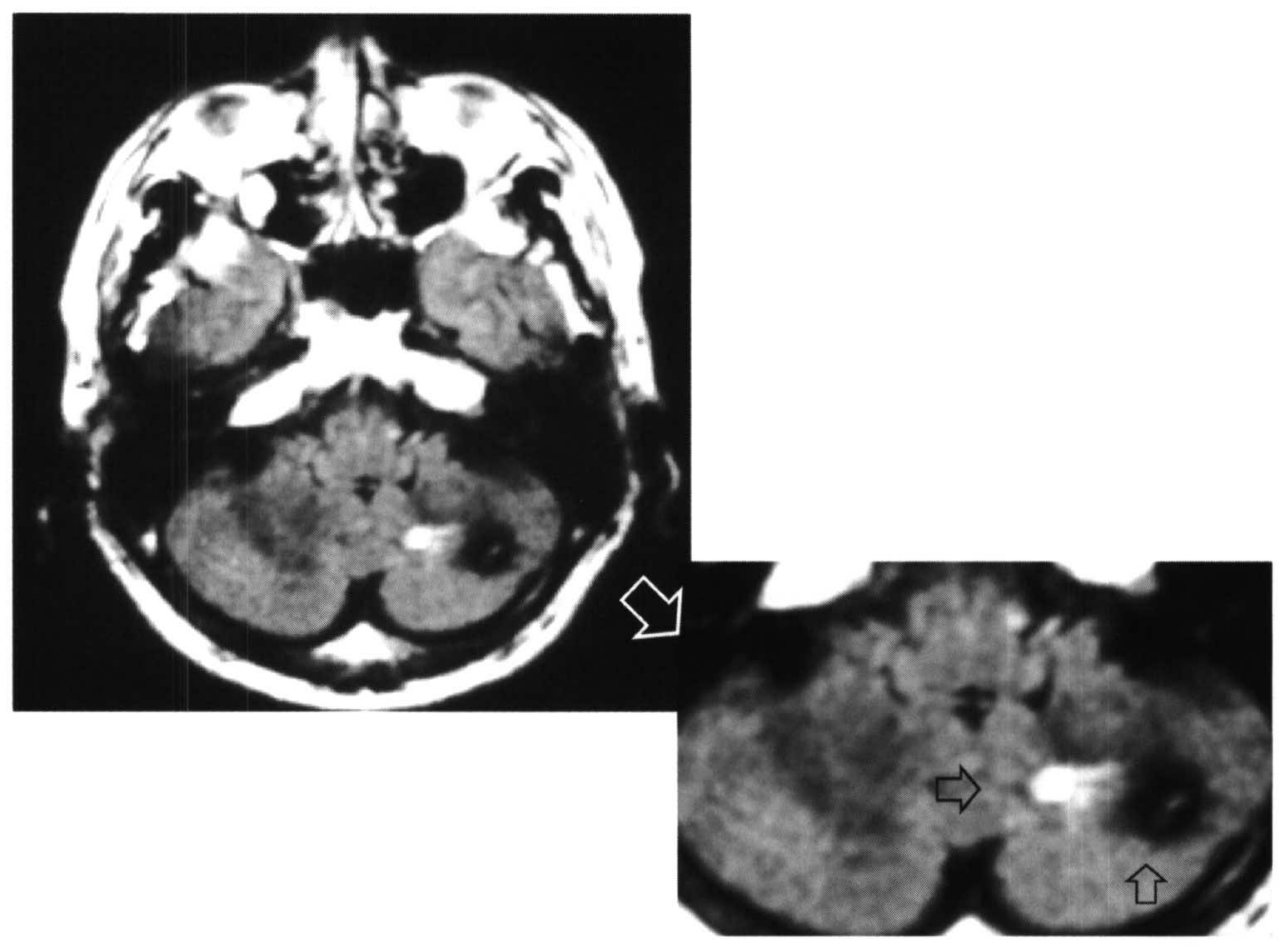

図 5 頭部 MRI (T2 强調)

左上の写真は全体図。右下は小脳部の拡大図。

海綿状血管腫である直径約 $10 \mathrm{~mm}$ の低信号 ( 矢印吕) の内側に静脈性血管腫である線状のやや払張した 血管様構造がみられた（右下の拡大写真の矢印

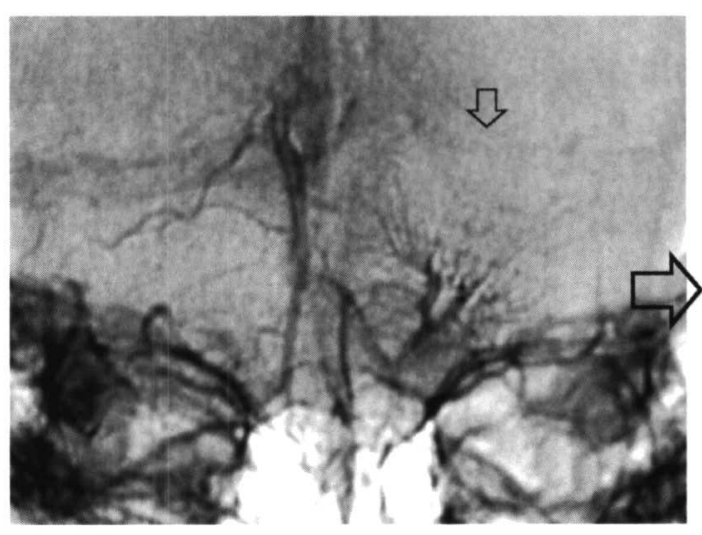

図6 左椎骨動脈造影

静脈相で後頭静脈洞から分岐する血管に umbrella sign（矢印々）を認めた。
ある。これだけ広い範囲にわたって障害されたに も拘わらず眼球運動障害が少なく重心動摇検査で

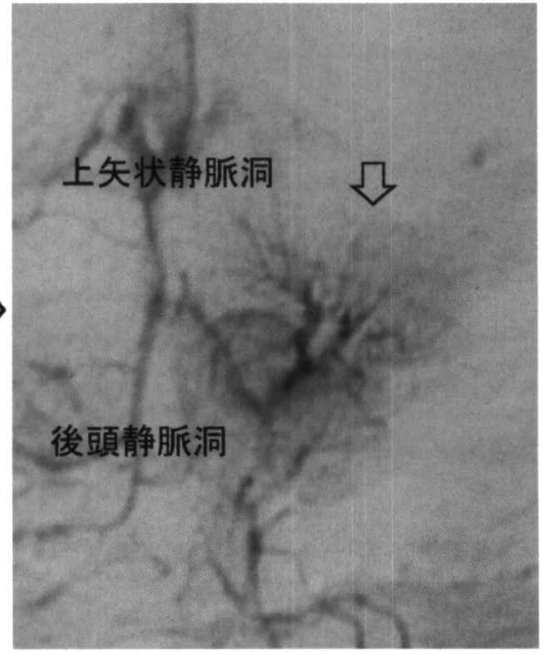

のみ異常がみられたことは, 今後このよらなめま

い疾患を診ていく上でひとつの啓蒙になるかと思 
ら。

治療法は出血の危険性が高い場合などを除いて は腫瘍全摘術が一般的である1)45)。本症例は低年 令，出血発症であることから手術を考えたが，腫 瘍が小さいことから術後脳硬塞を併発する可能性 があるため, 外来で経過観察して今後手術を行ら か否か本人と相談の上決める予定である。

\section{まとめ}

1。めまいで発症した小脳海綿状血管腫に静脈 性血管腫を合併した稀な一例を報告した。

2. 急激に発症するめまい患者の中には今回の ような症例も念頭に置くべきである。

\section{謝辞}

今回この論文をまとめるに当たり御指導いたた きした愛知医科大学耳鼻咽喉科名誉教授 石神 寛通先生，土岐市立総合病院脳神経外科 熊谷安 雄先生に感謝致します。

本論文の要旨は第107回遠近汇医学会学術講演 会 (浜松市)，第70回日耳鼻静岡県地方部会学術 講演会 (浜松市)，第62回めまい平衡医学会総会 （横浜市）に扎いて発表した。

\section{文献}

1）志和成紀，石井正則，杉本春美，他：めまい を主訴とした Cavernous Angioma の 1 例.

耳鼻展望 34: 4: 457-460, 1991

2 ）佐久間化, 大河内幸男, 馬場陽子, 他 : 難聴, めまいで発症した脳幹部海綿状血管腫の一症 例. 耳鼻臨床 補 43: 70-76, 1991
3）村岡賢一郎，伊勢田恵一，相原 寛，他： Venous angiomaを合併した脳幹部 cavernous angioma に対する診断と治療．香川中病医誌 22: $30-35,2003$

4) 今尾幸則, 矢野 高, 田辺祐介：橋に静脈性 血管腫と海綿状血管腫を合併した1手術例. 岐㚖市民病年報 17: 59-61, 1997

5 ）吉川茂樹, 池田佳充, 西平 修, 他 : めま い・難聴を主訴とした小児頭蓋内血管腫の 1 例. 耳鼻咽喉 39: 23-27, 1993

6) Van Calenbergh F, Demaerel P, Scoiot R, et al: Acquired cerebellar cavernous angioma following childhood radiotherapy in a patient with neurofibromatosis type 1 . Acta Neurol Belg 103: 103-106, 2003

7 ）佐藤光夫，仲野雅幸，笹沼仁一，他 : 多発性 脳海綿状血管腫の MRI 診断. 脳と神経 55 : 172-173, 2003

8) Del Curling O Jr, Kelly DL, Elster AD, et al : An analysis of the natural history of cavernous angioma. J Neurosurg 75: 702-708, 1991

原稿到着: 平成16年 8 月 2 日

別刷請求先 : 角谷昌昭

₹430-0917 静岡県浜松市常盤町144-6

静岡県厚生農業協同組合連合会遠州総合病院 耳鼻咽搌科

E-mail: m-sumiya@ken.ja-shizuoka.or.jp 